\title{
STRATEGY AND TACTICS OF APPEARING IN COURT: THEORETICAL APPROACH
}

Summary. The article focuses on the strategies and tactics of a judge's speech at a court hearing. Emphasis is put on the need to develop a theoretical structure on the basis of which it is possible to identify and study the discursive strategy, which is implemented by one of its participants, that is the strategy of the subject of discourse. In order to do this, the views of scholars on the concept of strategy are studied, the data on the strategies of the judge identified by researchers are given and the concept of discursive strategy is modified.

The intensive use of the terms strategy and tactics in linguistic research begins in the mid-80s of the twentieth century, due to the strengthening of the pragmatic approach to the analysis of linguistic factors, as well as changes in the consideration of isolated statements and study of their interaction within discourse. Recently, scientists have shown interest in the problem of strategies and are actively developing them. However, it should be noted that there is still no common understanding of the term "strategy". This is due to the fact that in various scientific areas only some aspects of this complex phenomenon are studied.

It is worth analyzing the approach to understanding the token strategy in different scientific fields. Interpretation of the concept of strategy varies depending on the material selected for analysis and the approach used: textual, psychological, rhetorical, cognitive, pragmalinguistic, psycholinguistic. The concepts of strategy and tactics are interdisciplinary: they are studied in pragmalinguistic and cognitological research, in communication theory and social psychology, etc. However, we are primarily interested in them in the context of judicial discourse.

Key words: legal discourse, strategy, tactics, communication, court, judge, court session, court speaker, discursive strategy, speech activity.

Problem setting. The popularity of the term "strategy" in science in general is accompanied by a lack of common interpretation. From the standpoint of constructing a speech in court - this concept is not exclusively linguistic, and does not require clarification of its content. However, it is worth considering the definition given by the authors of the New Explanatory Dictionary of the Ukrainian language: 1 . The art of preparing and conducting war and large-scale military operations; The science of warfare - the highest military science; 2 . The art of social and political leadership of the masses, which should determine the main direction of their actions, deeds; 3. Methods of actions, line of conduct of someone [1; Vol. 4, p. 417]. In psychology, the personality of the subject and his preferences stand side by side in the context of considering the strategy as a conscious choice of semantic and stylistic characteristics of the activity, which is also due to the specifics of the specified situation. The content of strategies is determined by the nature of the prediction, which exists as desired outcomes and changes in the situation, in accordance with the nature of feedback, which appears as the ability of the subject to respond to information coming through the feedback channel.

Analysis of recent researches and publications. We agree with L. Bailinson, who shares the thoughts of other scholars that it is unacceptable to reduce the role of the court to a silent observer of the duel and the winner's announcement, to perform only technical functions to ensure order in court, compliance with court proceedings. That is, the process of communication and construction of its participants' speeches in court is important. Communicative strategy is understood as a part of communicative behavior that is used to achieve a certain communicative intention, which is determined by the macro-intention of the speaker in relation to the dialogue as a whole; as a "way of operating information in order to change the behavior of the object of speech influence" [2, p. 318].

Judicial debate is a form of public, formal communication through a court speech, and, in some cases, a remark. In our opinion, in general, the success of a court speech depends on a combination of the following factors: 1 . Speaker (communicative attitude, knowledge of the subject of the court speech, communication skills); 2. Listeners (goals and motivation, preparation for the perception of the speech, the level of knowledge about the subject of the speech, socio-demographic composition, attitude to the speaker); 3. The text of the speech (content, structure, style); 4. Transmission way (verbal, visual); 5. Communicative situation [3, p. 185].

The court speaker, who often speaks in court proceedings, tries to do it in such a way that it does not resemble the previous one. This is a difficult task. The difficulty of such a task is to find those convincing and necessary words and comparisons that would bring pleasure, on the one hand, to the speaker, and, on the other hand, could impress the audience. Undoubtedly, this would help to solve the tasks set by the speaker. At the same time, it often happens that the speaker has repeatedly used in his court speeches certain comparisons and phrases before the same judge, and therefore such repetition is not new to the court. That is why court speakers always try to find novelty in the submission of material. Lawyers or prosecutors try to find such a novelty in strong comparisons [4, p. 75].

If we consider the strategies from a textual point of view, we can see that they contribute to the organization of the text, they are used to control the synthesis process in solving the problem of how to continue the text at each stage of the discourse.

From the standpoint of pragmalinguistic approach, strategy is defined as "a set of certain speech actions", "the chain of decisions 
of the speaker, his choice of certain communicative actions and language tools" [5, p. 227].

The cognitive approach presents the strategy as a "set of speech actions aimed at achieving communicative goals", which "involve planning the process of speech communication depending on the specific conditions of communication and personalities of communicators, as well as the implementation of this plan" [6, p. 86]. Speech activity in court is based on the strategy and tactics of speech behavior, and also involves such basic stages as planning and control. That is, the strategy appears as a "cognitive communication plan, which controls the optimal solution of communicative tasks of the speaker in the absence of information about the actions of the partner" [6, p. 87]. Awareness of the connection between strategy and mental activity allows us to interpret strategy as a "plan of action" formed in the mind of the individual.

When studying the strategies and tactics of a judge in judicial discourse, attention should be paid to the following provisions: 1) to consider these strategies as derived from the role of a judge an agent of judicial discourse; 2) to modify the concepts of discursive strategy accordingly. Different participants take part in judicial discourse, and therefore their discursive strategies are different. Each of them is determined institutionally and is realized through the institutional nature of judicial discourse.

If the field of judicial communication is common to all participants in the trial, the roles that these participants play in this court session are different. These institutional roles determine the discursive strategies of the participants, but in accordance with their rights and responsibilities.

Article's main body. The implementation, practical fulfillment of language strategy involves the performance of a number of communicative steps in the process of forming a discourse. These steps must be consistent and have a hierarchical structure that corresponds to the model of the planned discourse.

In general, the strategies are divided into two groups by the nature and purposes of global character: general aimed at achieving common social objectives (establishment and maintenance of status, exercise of power, confirmation of solidarity with the group, etc.) and partial ones, which can characterize a certain conversation with precise goals (to request, to comfort, to support, etc.); as well as the functions and nature of their content: basic (semantic: discrediting, persuasion, threats, requests; cognitive) and auxiliary, covering pragmatic, dialogical and rhetorical strategies. The strategy, which at a certain stage of communicative interaction is the most significant in terms of the hierarchy of motives and goals, is considered as the main one. In most cases, the main strategies are those that are directly related to the impact on the recipient, his model of the world, value system, his behavior (both physical and intellectual). Auxiliary strategies contribute to the effective organization of dialogue, the optimal impact on the recipient [5, p. 26].

According to another point of view, there are propositional strategies, local connectivity strategies, production strategies, macro-strategies, as well as schematic, scenario, stylistic and conversational strategies.

A. Belova's classification is, in our opinion, the most comprehensive. The scientist takes into account such diverse criteria as social factors (ethnicity, social status, gender, age, time, personality), the nature of communicative signs, psychological compatibility of participants in the communicative process, the figure of the addressee and the addressee, communicative purpose, divides them into: 1) universal and ethnically specific; 2) commonly used and individual; 3) commonly used and age-long; 4) unisex and gender-labeled; 5) verbal and nonverbal; 6) a temporal and limited in time; 7) cooperative and conflict; 8) addressee-oriented and destination-oriented; 9) informative and motivating [7, p. 14].

Tactics - "1. An integral part of the art of war, which includes the theory and practice of training, organization and conduct of combat; // subject on the theory of combat practice. 2. A set of techniques and methods of socio-political struggle. 3. Ways, methods of achieving a certain goal; someone's line of behavior" [1, Vol. 4, p. 485]. According to scientists, strategy and tactics are always interrelated. The implementation of the strategy as a whole depends on well thought-out tactical moves. In this regard, it is also neatly noted that in a dynamic communicative space there may be a change in the position of communicative strategies / communicative tactics: the same phenomenon can be characterized as a strategy, or as a tactics within another strategy.

At the same time, there exists the views of scientists who argue about the synonymy of the concepts of strategy and tactics. Closer to us is the idea that tactics in speech in general and in judicial speech in particular, may involve one or more speech actions. These actions are outlined in the strategy and serve to solve the communicative task set by the court speaker. That is, these actions are part of his strategy.

Tactical actions in court negotiation cover both practical moves and language and speech techniques. According to R. Katsavets, the main purpose of describing strategies is the problem of identifying typical tactics that implement certain strategies. The flexibility of speech strategies is determined by the possibilities of their implementation through a variety of speech tactics and communication moves, as well as the integrated use of language resources and methods of speech influence. The researcher notes that since tactics makes the impression of the units that are really available for study, they are probably a practical tool of the speaker [8, p. 137]. In scientific research we find other opinions. Thus, I. Trufanova believes that the concept of tactics is related to the concept of a language genre or its component; to the concept of a speech act as a speech action that coincides with it and is included in the language genre; to the concept of strategy as a method of its implementation [9, p. 60].

The science of criminal procedure, which combines strategy and tactics, traditionally distinguishes three main components: 1) the division of three main criminal procedural functions: prosecution, defence and case resolution; 2) procedural equality of the parties; 3 ) the leading and active role of the court in the process. The specificity of such an understanding of adversariality lies in the construction of the procedural order for the study of evidence in court and in the organization of procedural relations associated with this study, which provides an active role of the prosecutor and defence counsel as well as and the court. All their actions are woven into the overall strategy, but each differs in its own tactics. The activities of the participants in the process - the accused, the defence counsel, the victim and others, are aimed at ensuring their subjective interests and aimed at clarifying the circumstances that correspond to these interests, and therefore they all form their own tactics of speech or remarks in court within the same strategy. That is, their activity has a one-sided tactical direction. The activity of the prosecutor - a public prosecutor, if he is deprived of the function of overseeing the legality of procedural activities in the judicial stages, also acquires a one-sided character. The requirement to ensure the legal- 
ity and validity of the accusation for the prosecutor may mean no more than for the defence counsel to be objective and not to go beyond the law in search of remedies.

The intention of the threat, which is present in their speech tactics, speech genre and speech act is interesting in the context of the judicial activity of the above-mentioned participants in the trial. However, there is still a difference. It consists of different levels of abstraction. It is thought that the concepts of speech tactics and speech action are identical, but speech tactics are not considered in isolation as a speech act, but are a method of implementing a speech strategy.

Interpretation of tactics in various scientific studies can explain them as specific ways to implement strategies that are purposefully aimed at clear changes in parts of the addressee's consciousness in the right direction for the addressee. According to researchers, speech tactics and strategy are systematically linked as part and whole, as species and genus, so we can assume that they are defined in accordance with each other. The choice of a particular strategy and appropriate tactics within it is determined by a set of certain factors. In particular, it is believed that the choice of tactics is determined by the types of language personality of the participants in the communication process; national and cultural specifics of language personality behavior.

All of the above is aimed at confirming certain provisions of the concept of discursive strategy, which has a communicative and cognitive nature. An important step is also to establish the correlation of strategy and tactics in the context of understanding the speech strategy as a whole. This helps to take advantage of the linguistic practice of strategy analysis. At the same time, in the applied analysis by the level of abstraction we recognize speech strategies and tactics that are correlated as a whole and a part; if the means of implementing tactical tasks form a set that can be diversified by a certain criterion or criteria, we distinguish techniques within the tactics; if such diversification is not possible, we analyze and systematize the means of implementing tactics.

If we analyze the existing classifications of strategies and tactics of the judge, we note that their creators do not argue the theoretical basis or criteria for diversification. In particular, the judge's strategies include self-presentation and presentation strategies, within which the judge applies tactics of group identification, distancing, etc. The tactics of logical inference, the tactics of proving the insolvency of claims or evidence together constitute the strategy of establishing objective truth, the tactics of repetition - the strategy of control confirmation, the tactics of suggestion, the tactics of rational persuasion, the tactics of consent - the strategy of cooperation, the tactics of compliance insistence on certain actions - a strategy of appealing to the authorities [6, p. 86].

A lawyer, a participant in criminal proceedings, using logical methods of thinking, evaluates, compares the properties (characteristics) of different objects, the results of their interaction. However, the content of the formulated conclusions will depend on the depth of the lawyer's knowledge of these subjects. Superficial, shallow knowledge of them often leads to erroneous conclusions and subsequent wrong actions. But even in the cases where the lawyer's thinking in court was logically expressed and well-grounded, so that it logically followed from the details of the criminal proceedings agreed with the client, a plan for further strategy of joint activities was outlined, in the course of its implementation, errors in actions are possible, that is, in the implementation of the planned algorithm, in a set of procedural actions, in some of them. At this stage, procedural and tactical errors may occur. If a lawyer, as a specialist in the field of law, does not know the requirements of criminal procedure law and, therefore, does not comply with them, it is his/ her mistake. In our opinion, in most cases we should talk about the procedural nature of the typical mistakes of a lawyer in criminal proceedings, which are of an unconscious nature and are the result of his/her conscientious delusion in the process of cognitive activity and decision-making [10, p. 68].

There are three types of tactics that are consonant with the constructed reality: 1) the immediate reality of the courtroom; 2) the events that have led to the trial; 3) the actual scope of the law. These tactics accordingly contribute to the observance of general norms of conduct in the courtroom help to increase the effectiveness of the testimony process and influence its content; clarify legal issues. In parallel, there is a variety of classification of judge tactics. In an interrogation situation, these tactics fall into three groups: 1) the tactics of creating the primary reality, control of the procedure (orders regarding court proceedings, orders for the future, permission to leave, control of voice audibility, reminders of responsibilities and rights ensuring, requests for compliance with the norms of conduct); 2) tactics of depicting the secondary reality: control of the content of testimonies (control of temporary norms of testimonies, determination of the range of topics, indication of relevance / irrelevance of facts, specification and clarification of information, control of definitions, stimulation of conclusions, direct request for information); 3 ) tactics of addressing the reality of law: legal explanations (explanation of the principles of litigation, clarification of legal categories, qualification of actions in terms of law, intersection of legal comments). All these tactics may overlap during the interrogation process [11, p. 16-17].

Conclusions. Thus, the role of a judge in the trial can be considered as the basis of a judge's discursive strategy. However, these considerations and developments about the concept of the role of the subject of discourse can be defined as fundamental only if certain inaccuracies are taken into account. Determinative fact in this situation is that the judge plays a certain general role, which is based on stereotypes and ideas or declarative knowledge of the role rules associated with this function in society.

In the process of implementation of this role in different genres or communicative situations of judicial discourse, behavioral standards acquire values that correspond to procedural knowledge and serve as guidelines in the application of declarative knowledge, involving only some of its elements.

For example, a judge has specific rights and responsibilities in a court hearing, but these rights and responsibilities will be somewhat different during the Judicial Council, the Congress of Judges, the Forum of Judges and other events that take place in the community of judges, as well as, in public speeches, interviews, essays, which are considered hybrid genres of judicial discourse. It is also important not to take lightly the fact that a judge is an active participant in the process of justice, law enforcement and lawmaking.

Thus, it can be argued that, depending on the contextual factors, the general role is embodied in the discourse in certain specific roles. Criminal proceedure is complex and multi-stage. Therefore, the court statement is the most responsible for each participant: prosecutor, defense counsel, victim, suspect, witnesses. Consequently, judicial discourse from the standpoint of a professional approach to training requires in-depth, thorough, all-round training. 


\section{References:}

1. Яременко В.В., Сліпушко О.М. Новий тлумачний словник української мови : у 4-х т. Київ, 2001. Т. 4. 944 с.

2. Бейлинсон Л.С. Профессиональный дискурс: признаки, функции, нормы (на материале коммуникативной практики логопедов) : дис. ... докт. филол. наук: 10.02.19. Волгоград, 2009. 339 с.

3. Загурський О.Б. Судові дебати в кримінальному процесі: правові та психологічні проблеми : дис. ... канд. юрид. наук: 12.00.09. Івано-Франківськ, 2003. 215 с.

4. Ясинок М.М. Судові дебати: право, психологія, риторика : монографія. Київ : Алерта, 2014. 171 с.

5. Кобзєва О.О. Принцип розробки типології стратегій американського судового дискурсу. Сучасний стан $і$ перспективи лінгвістичних досліджень та проблеми перекладу : тези доповідей Всеукраїнської наукової конференції пам'яті доктора філологічних наук, професора Д.І. Квеселевича, 17 травня 2013 р. Житомир : ЖДУ імені Івана Франка, 2013. С. 26-27.

6. Кобзєва О.О. Реалізація мовленнєвого впливу в судовому дискурсі. Психолінгвістика в сучасному світі - 2013 : тези доповідей VIII Міжнародної науково-практичної конференції, 18-19 жовтня 2013 р. Переяслав-Хмельницький : ДВНЗ «Переяслав-Хмельницький державний педагогічний університет імені Григорія Сковороди», 2013. С. 85-86.

7. Бєлова А.Д. Поняття «стиль», «жанр», «дискурс», «текст» у сучасній лінгвістиці. Іноземна філологія. Київ : КНУ імені Т. Шевченка, 2002. Вип. 32. С. 11-14.

8. Кацавець Р.С. Мова у професії юриста : підручник 2-ге вид. Київ, 2007. $304 \mathrm{c}$.

9. Труфанова И.В. О разграничении понятий: речевой акт, речевой жанр, речевая стратегия, речевая тактика. Филологические науки. 2001. № 3. C. 56-65.

10. Дяков В.С. Гносеологічна і правова природа виправдувального вироку: дис. ... канд. юрид. наук: 12.00.09. Київ, 2016. 258 с.

11. Дубровская Т.В. Судебный дискурс : речевое поведение судьи : автореф. дис. ... канд. филол. наук: 10.02.19. Саратов, 2009. 26 с.
Сковронський Д. Стратегія і тактика виступу в суді: теоретичний підхід

Анотація. У статті акцентовано увагу на стратегіях і тактиках виступу судді в судовому засіданні. Наголошено на необхідності розроблення теоретичної конструкції, на основі якої можна визначити і вивчити дискурсивну стратегію, яка реалізується одним із його учасників, тобто є стратегією суб'єкта дискурсу. Із цією метою вивчено погляди науковців на поняття стратегії, наведено дані про виявлені дослідниками стратегії судді, модифіковано поняття дискурсивної стратегії.

Інтенсивне вживання термінів «стратегія» і «тактика» у лінгвістичних дослідженнях починається із середини 80-х років $\mathrm{XX}$ століття, що зумовлено посиленням прагматичного підходу до аналізу мовних чинників, а також зміною розгляду ізольованих висловлювань, вивчення їхньої взаємодії в межах дискурсу. Останнім часом науковці проявляють зацікавленість проблемою стратегій, ведуть їх активну розробку. Проте необхідно зазначити, що дотепер немає єдиного розуміння терміна «стратегія». Це зумовлюється тим, що в різних наукових напрямах досліджуються лише окремі аспекти цього складного явища.

Варто проаналізувати підхід до розуміння лексеми «стратегія» у різних наукових галузях. Інтерпретація поняття «стратегія» варіюється залежно від обраного для аналізу матеріалу та від застосованого підходу: текстологічного, психологічного, риторичного, когнітивного, прагмалінгвістичного, психолінгвістичного. Поняття стратегії і тактики є міждисциплінарними: вони вивчаються у прагмалінгвістичних і когнітологічних дослідженнях, у теорії комунікації та соціальній психології тощо. Однак нас воно цікавить насамперед у контексті судового дискурсу.

Ключові слова: правовий дискурс, стратегія, тактика, комунікація, суд, суддя, судове засідання, судовий промовець, дискурсивна стратегія, мовленнєва діяльність. 